\title{
Statyba
}

\section{PULSE LENGTH DEPENDENCE ON THE DECAY OF THE INTEGRATED PULSE ENERGY}

\section{J. Stauskis}

To cite this article: V. J. Stauskis (2000) PULSE LENGTH DEPENDENCE ON THE DECAY OF THE INTEGRATED PULSE ENERGY, Statyba, 6:3, 206-212, DOI: $\underline{10.1080 / 13921525.2000 .10531588}$

To link to this article: https://doi.org/10.1080/13921525.2000.10531588

曲 Published online: 26 Jul 2012.

Submit your article to this journal $\pi$

III Article views: 33 


\title{
INTEGRUOTO IMPULSO ENERGIJOS SLOPIMO PRIKLAUSOMYBE் NUO SKIRTINGŲ IMPULSO ILGIŲ
}

\author{
V. J. Stauskis \\ Vilniaus Gedimino technikos universitetas
}

\section{Ivadas}

Skirtingi impulso ilgiai gali gali duoti ir skirtingus skaičiavimų rezultatus. M. Vorlanderis ir H. Bietzas [1] nagrinejja aštuonis aidejimo laiko matavimų metodus sužadinant garso lauką triukšmu ir impulsu. Aidejjimo laiko tikslumui padidinti ir triukšmo fono lygiui sumažinti jie siūlo naudoti impulso integravimo limitą, t. y. kada impulso dalis yra nupjaunama. Tačiau autoriai nenurodo, kokio ilgio impulsą geriausiai naudoti praktiniams tyrimams. Atliekant matavimus automatiniu režimu nustatoma, kokioje vietoje reikia nupjauti impulsą. Pasigendama aidèjimo laiko dažninès priklausomybès nuo skirtingų ilgių impulsų.

A. Landeby ir kiti [2] siūlo metodą, leidžianti nustatyti taška, kuriame reikia nupjauti impulsa. Tam jie taiko rms vidurkinimo metodą ir ši procesą pakartoja penkis kartus. Radus toki tašką galima atlikti impuso integravimą ir kartu sumažinti triukšmo fono itaką reverberacijos laikui. Straipsnyje nagrinèjamas tik nefiltruotas signalas. Nèra dažninès priklausomybès ir praktiniụ pavyzdžių.

Ning Xiangas [3] skirtingus to paties impulso slopimus aprašo funkcijomis ir naudoja viršutini integravimo limita. Autorius parodo priklausomybę tarp signalo-triukšmo santykio ir aidejimo kreivių slopimo.

D. Morganas [4] nagrinèja aidejjimo kreivès slopimo priklausomybę nuo skirtingo ilgio impulsu pagal 20.40 ir $60 \mathrm{~dB}$ signalo-triukšmo santykị. Tuo praplečiamas energijos slopimo dinaminis diapazonas.

Šiuose darbuose autoriai nepateikia praktiniu pavyzdžių, kokią itaką skirtingo ilgio impulsai turi energijos slopimo kreivèms ir įvairių dažnių aidẻjimo laikams. Neaišku, ar taikant šiuos metodus nustatytas impulso ilgis duoda geriausius rezultatus. Be to, impulso integravimas vykdomas pagal Schroederio metodą nesumažinant patalpos akustinio triukšmo fono.
Straipsnio tikslas - nustatyti energijos slopimo ir aidèjimo laikų dažninę priklausomybę nuo skirtingų impulso ilgių, taikant Schroederio integravimo metoda, kada triukšmo fonas yra sumažintas, o garso laukas sužadinamas impulsu.

\section{Nefiltruoto ir filtruoto signalo garso lauko slopimo priklausomybẻ nuo skirtingų impulso ilgių}

Nagrinèdami foninio triukšmo sumažinimo itaka reverberacijos laikui autoriai taikẻ Schroederio integralinio impulso atsako slopimo metodą [5]. Nustatydami taško, kuriame reikia nupjauti impusa, autoriai netyrinejo, kokią jtaką tai turés skirtingų dažnių aidejjimo laiko reikšmėms. Be to, svarbu žinoti, ar tokiu atveju apatinis slopimo lygio aproksimavimo taškas turès reikšmę $-45 \mathrm{~dB}$, kuri būtina norint išmatuoti standartini aidejjimo laiką $T_{35}$. Tai ypač svarbu esant žemiesiems dažniams, kai signalo-triukšmo santykis paprastai yra mažas ir nepakankamas. Tokiu atveju, atliekant matavimus automatiniu režimu, galima gauti matavimų paklaidas. Dažnai, esant žemiesiems dažniams visiškai negalima tiesiogiai išmatuoti standartinio aidèjimo laiko $\mathrm{T}_{30}$.

Tyrimams pasirinkime nedidelę salę, kurioje groja kamerinis orkestras. Jos ilgis $13.6 \mathrm{~m}$, plotis $10,7 \mathrm{~m}$ ir aukštis $7 \mathrm{~m}$. Salëje yra tik 170 pusiau minkštų kèdžių. Impulsinis garso šaltinis - 9-to kalibro garsinis pistoletas yra scenoje, 1,5 m nuo priekinès sienos. Matavimu mikrofonas - $6 \mathrm{~m}$ atstumu nuo garso šaltinio.

Tyrimams pasirinkti 6 skirtingi impulsu ilgiai -2000 . $2500,3000,3500,4000$ ir $4500 \mathrm{~ms}$. Tokia skirtinga impulsu ilgių gradacija leis aiškiai pamatyti, kokio ilgio impulsas geriausiai apibūdina slopimo procesą.

1 pav. pavaizduotas maksimalaus ilgio impulso garso energijos slopimas logaritminiu masteliu.

Nefiltruoto signalo garso laukas slopsta apytikriai iki $2000 \mathrm{~ms}$. o toliau prasideda triukšmo fonas, kuris yra 
nesumažintas. Grafikas rodo, kad reikia koncentruoti dèmesi i impulso ilgius, didesnius negu $2000 \mathrm{~ms}$.

E, sant. vien.

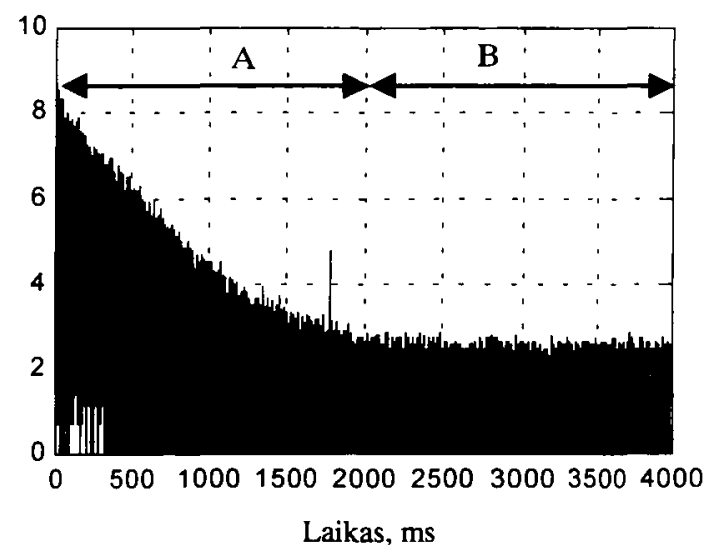

1 pav. Garso lauko energijos slopimas koncerty saleje. Salèje yra tik 170 kèdžių. A - naudingo signalo zona; B triukšmy zona

Fig 1. The sound energy decrease in the concert hall. 170 chairs in the hall. A - useful signal zone; B - noise zone

\section{$E, d B$}
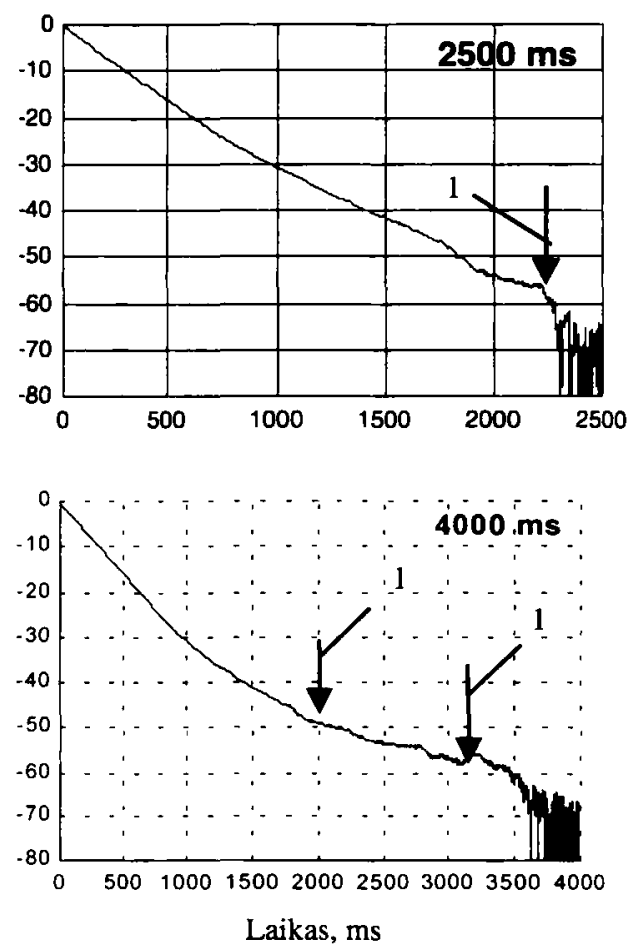

Praktiniams rezultatams labai svarbu, ar triukšmo fonas bus sumažintas, ar ne. Triukšmo fonui sumažinti autorius siūlo tokią formulę:

$$
\left\langle S^{2}(t)\right\rangle=N \int_{t}^{\infty}\left(p^{2}(\tau)-\left\langle p_{r}\right\rangle(\tau)^{2}\right) d \tau
$$

čia $\left\langle p_{n}\right\rangle^{2}$ - vidutinis kvadratinis triukšmo slègis. kuris randamas pagal formulę:

$$
\left\langle p_{t r}\right\rangle^{2}=\left(\frac{1}{t_{2}-t_{1}}\right) \int_{t_{1}}^{t_{2}} p_{t r}^{2}(\tau) d \tau,
$$

čia $t_{2}$ ir $t_{1}$ - triukšmo fono intervalas.

2 pav. linijiniu masteliu pavaizduota, kaip slopsta garso energija, esant skirtingiems impulso ilgiams taikant garso lauko slopimo integravimo metoda. kai triukšmo fonas yra sumažintas.

$2500 \mathrm{~ms}$ ilgio impulsas yra per trumpas, nes negalime teisingai ivertinti triukšmo fono laiko intervalo. Šio ilgio impulsas tyrimams yra netinkamas. Tyrimams geras impulso ilgis yra $3000 \mathrm{~ms}$. Tuo tarpu $3500 \mathrm{~ms}$ ilgis jau gali būti per didelis ir matavimų rezultatuose gali atsirasti klaidu. Kai impulso ilgis padideja iki $4000 \mathrm{~ms}$, tai pradedant $2000 \mathrm{~ms}$ slopimas skiriasi nuo atvejo, kai impulso $\mathrm{E}, \mathrm{dB}$
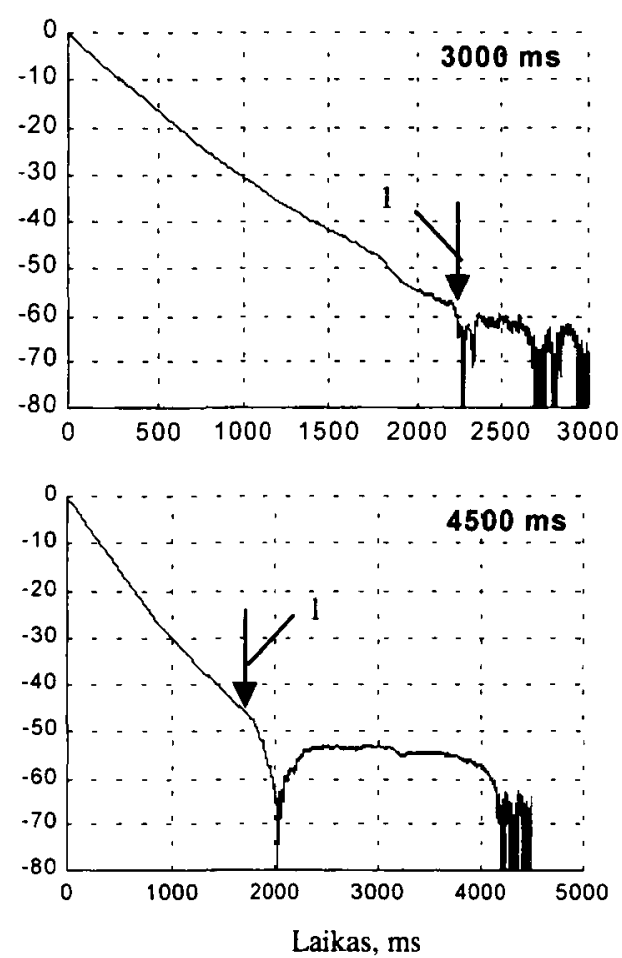

2 pav. Garso lauko energijos slopimo priklausomỳbè nuo laiko ir impulsų ilgio. 1 - maksimalaus slopimo riba Fig 2. The dependence of sound energy decrease on time and pulse length. 1 - maximum decrease limit 
ilgis yra 2500 ir $3000 \mathrm{~ms}$. Šių impulsụ triukšmy fonas prasideda nuo $2300 \mathrm{~ms}$, o $4000 \mathrm{~ms}$ ilgio impulso jau nuo 3200 - 3300 ms. Visiškai tyrimams netinkamas maksimalus impulso ilgis $4500 \mathrm{~ms}$. Šiuo atveju triukšmų zona prasideda labai anksti - nuo $1800 \mathrm{~ms}$, tuo tarpu trumpam $2500 \mathrm{~ms}$ impulsui ji prasideda gerokai vèliau - po 2300 ms.

Aiškesnị vaizdą gausime, pavaizdavę slopimą kitu masteliu (žr. 3 pav).

Impulsas, kurio ilgis $2000 \mathrm{~ms}$, analizei, aišku, yra netinkamas, nes yra per trumpas ir apima naudingo signalo dalị. Impulsụ, kuriụ ilgiai didžiausi ir lygūs 4000 ir $4500 \mathrm{~ms}$, labai skiriasi energijos slopimai baigiamojoje dalyje ir analizei taip pat netinkami. Ir tik impulsu, kuriu ilgiai 2500, 3000 ir $3500 \mathrm{~ms}$, yra beveik vienodi energijos slopimai.

4 pav. pavaizduota, kaip garso lauko energijos slopimas priklauso nuo dažnio.

Tyrinejjant energijos slopimus svarbiausia nustatyti, koks yra maksimalus slopimas. Nuo jo atmesdami -10 dB gausime taška. kuris leis nustatyti, koki aidejjimo laiką galime apskaičiuoti. Esant $63 \mathrm{~Hz}$ dažniui garso laukas slopsta beveik vienodai - iki $18 \mathrm{~dB}$. Toliau slopimai skiriasi. Ilgiausias - $4500 \mathrm{~ms}$ ir trumpiausias - $2500 \mathrm{~ms}$ impulsu slopimai po $-18 \mathrm{~dB}$ yra labai staigūs ir nuslopsta iki $-30 \mathrm{~dB}$. Tačiau, kaip matyti iš 3 pav., slopimui itakos jau turi triukšmo fonas. Taigi patiems žemiausiems dažniams trumpiausias ir ilgiausias impulsas skaičiavimams yra netinkami. Didžiausio energijos slopimo yra impulsas, kurio ilgis yra $3000 \mathrm{~ms}$. Po $1700 \mathrm{~ms}$ energija nu-

$E, d B$

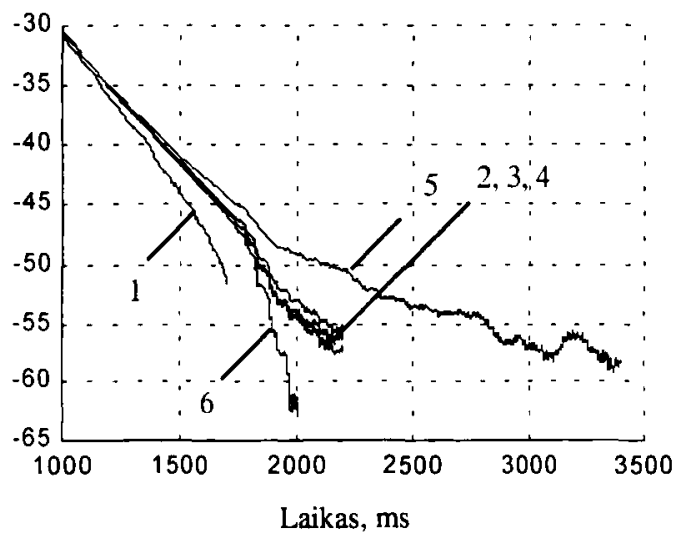

slopsta $-30 \mathrm{~dB}$. Taigi šiam dažniui galima išmatuoti aidèjimo laiką aproksimuojant slopimą nuo $0 \mathrm{iki}-20 \mathrm{~dB}$.

Didèjant dažniui, padetis keičiasi. Kai jis yra $100 \mathrm{~Hz}$, energija nuslopsta - 35-37 dB, kai impulso ilgiai 2500 ir 4000 ms. Didžiausia slopimą - $42 \mathrm{~dB}$ duoda ilgiausias impulsas - $4500 \mathrm{~ms}$, nors tai ir kelia kai kuriu abejonių. Tada galime išmatuoti aidejjimo laiką nuo 0 iki $-30 \mathrm{~dB}$.

Esant $125 \mathrm{~Hz}$ oktaviniam dažniui, mažiausio maksimalaus slopimo - $40 \mathrm{~dB}$ yra trumpiausias $2500 \mathrm{~ms}$ ilgio impulsas. Didžiausio slopimo - $50 \mathrm{~dB}$ yra ilgiausias 4500 ms impulsas. Taigi šiam dažniui jau galime išmatuoti ir standartini aidèjimo laiką.

Kai dažniụ diapazonas $250-2000 \mathrm{~Hz}$, maksimalus energijos slopimas yra pakankamas ir siekia - 50-60 dB. Kai dažnis $4000 \mathrm{~Hz}$, baigiamoji slopimo dalis labai priklauso nuo impulso ilgio. tačiau. kadangi slopimas visais atvejais siekia apie - $55 \mathrm{~dB}$, tai standartini aidejimo laiką nepriklausomai nuo to galime išmatuoti teisingai.

Vadinasi, impulsu ilgiai turi ịtakos tik skaičiuojant žemuju dažniụ aidejjimo laiką. Kai dažniai yra 63$100 \mathrm{~Hz}$, geriausią maksimalų slopimą duoda impulsas, kurio ilgis $3000 \mathrm{~ms}$, o dažniams $125 \mathrm{~Hz}$ ir didesniems geriausią slopima duoda impulsai, kurių ilgiai yra 3000$4000 \mathrm{~ms}$.

Verta panagrinèti, kaip kinta energijos slopimas toje pačioje saleje, kai joje pasikeičia akustinès sąlygos - joje yra 60 žiūrovų ir gobelenai, sukabinti ant visų sienų. Energijos slopimas pavaizduotas 6 pav.

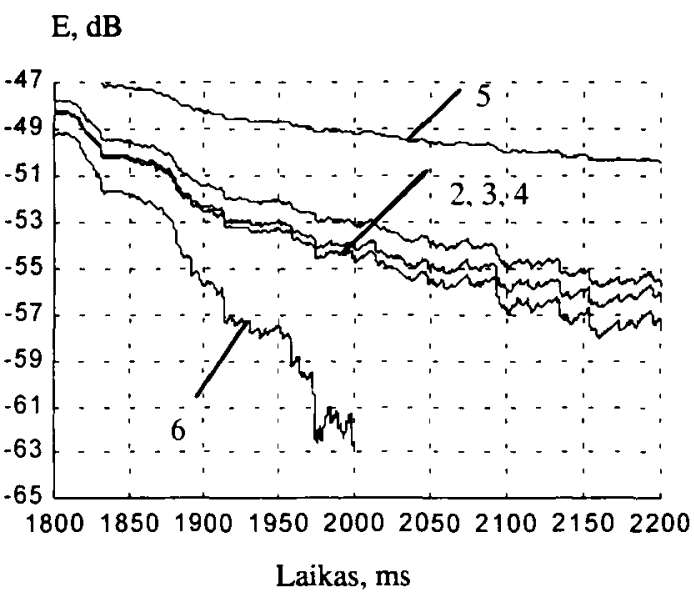

3 pav. Nefiltruoto signalo garso energijos slopimas priklausomai nuo impulso ilgio. Salèje yra tik 170 kẻdžių. $1-2000,2-2500,3-3000,4-3500,5-4000$ ir $6-4500 \mathrm{~ms}$

Fig 3. The dependence of sound energy decrease on pulse length. Only 170 chairs in the hall. $1-2000$, $2-2500,3-3000,4-3500,5-4000$ ir $6-4500 \mathrm{~ms}$ 
$\mathrm{E}, \mathrm{dB}$
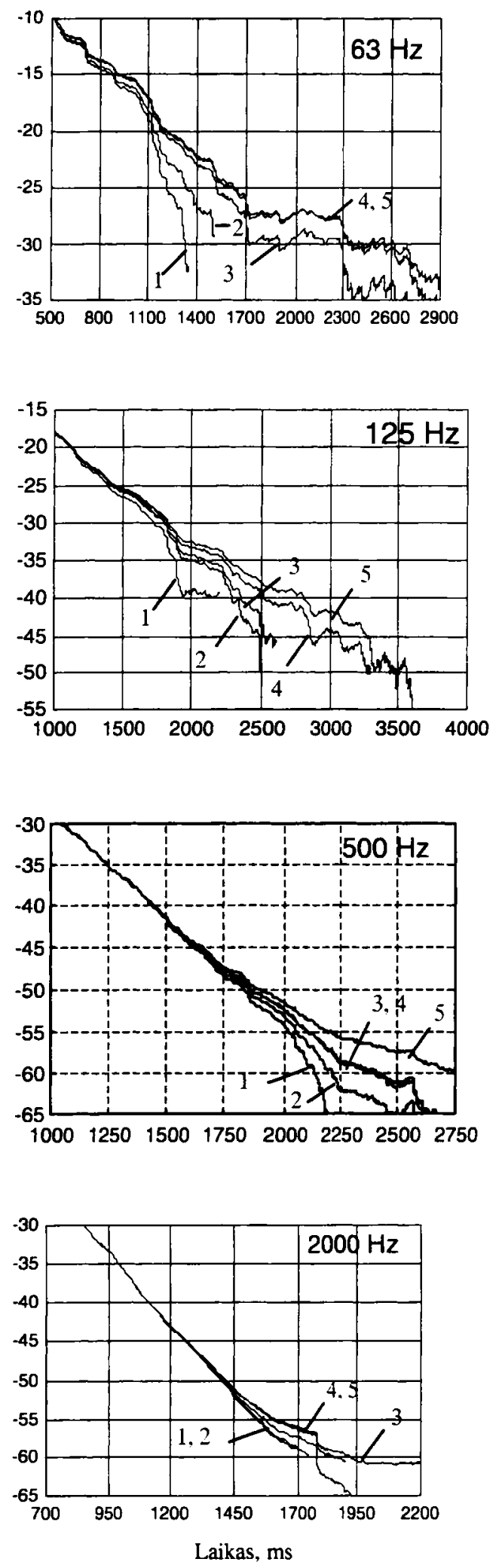

$E, d B$
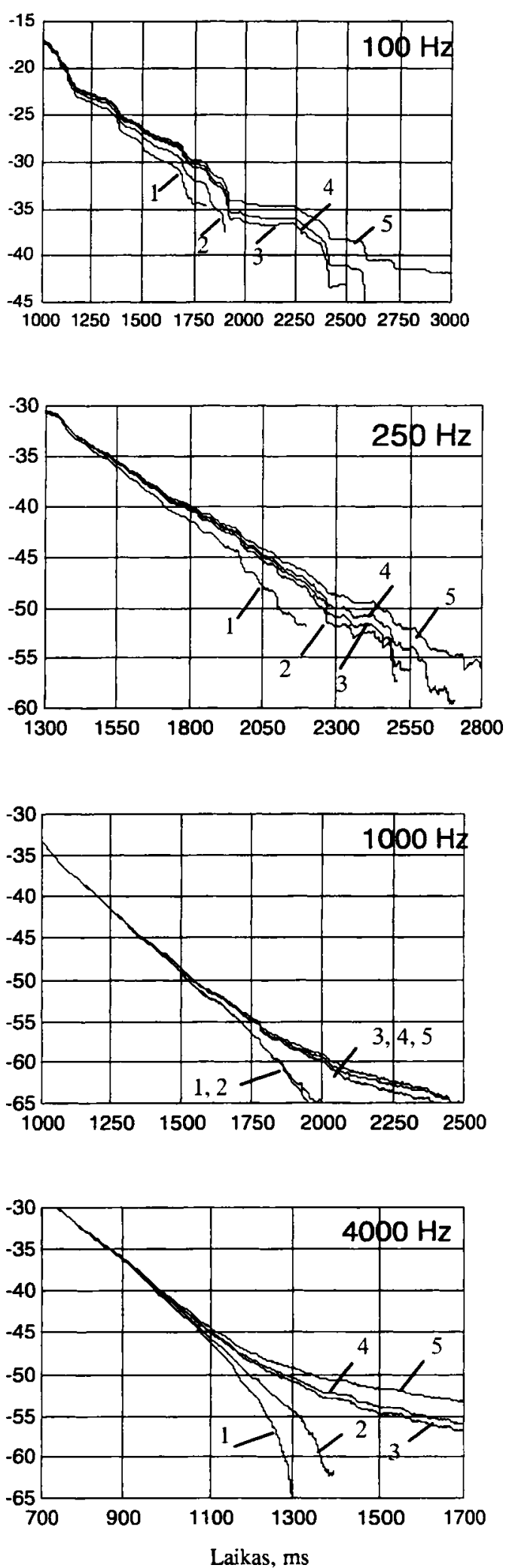

4 pav. Garso lauko energịjos slopimas priklausomai nuo dažnio ir impulso ilgio. Salẹje yra tik 170 kèdžių. 1 - 2500, 2 $3000,3-3500,4-4000$, ir $5-4500 \mathrm{~ms}$

Fig 4. The dependence of sound energy decrease on frequency and pulse length. Only 170 chairs in the hall. $1-2500$, $2-3000,3-3500,4-4000$, ir $5-4500 \mathrm{~ms}$ 
E, sant. vien.

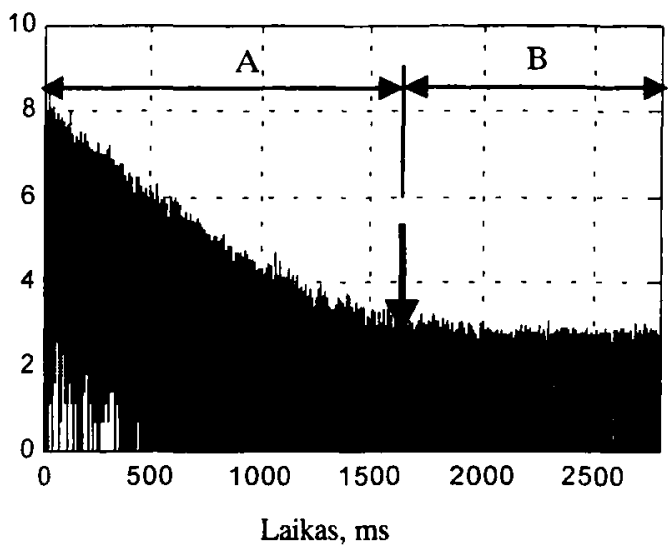

5 pav. Garso lauko energijos slopimas koncertų salẹje. Joje 170 kèdžiụ. 60 žiūrovų ir gobelenai ant sienų. A - naudingo signalo zona; B - triukšmų zona

Fig 5. The decrease of the sound energy in the concert hall. 170 chairs in the hall, 60 listeners and tapestry on the walls. A useful signal zone; $B$ - noise zone

Šiuo atveju energija slopsta greičiau negu pirmuoju atveju ir triukšmo fonas prasideda anksčiau - apytikriai nuo $1600 \mathrm{~ms}$.

Energijos slopima galima pavaizduoti kitu masteliu. (žr. 6 pav).

Kai saleje dar yra żiūrovu ir ant sienu kabo gobelenai, tai energijos slopimas yra beveik vienodas, kai impulsų ilgiai $2000-2800 \mathrm{~ms}$. Geresni slopimą šiuo atveju duoda ilgiausias - $2800 \mathrm{~ms}$ ilgio impulsas. Tuo tarpu, kaip matyti iš 3 pav., ilgiauso impulso energijos slopimas yra nepriimtinas.

Maksimalūs energijos slopimai

Maximum energy decrease
E, dB

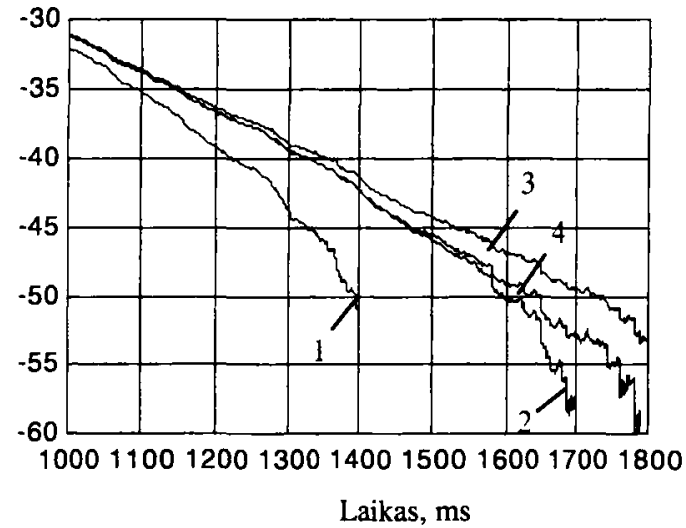

6 pav. Nefiltruoto signalo garso energijos slopimas priklausomai nuo impulso ilgio. Salèje yra 170 kèdžiu. 60 žiūrovu ir kabo gobelenai ant sienụ. $1-1600,2-2000,3-2400,4$ $2800 \mathrm{~ms}$

Fig 6. The dependence of sound energy decrease on a nonfiltred signal of a pulse length. Only 170 chairs in the hall, 60 listeners and tapestry on the walls. $1-1600,2-2000,3-2400$, $4-2800 \mathrm{~ms}$

7 pav. pateikiamas filtruoto signalo garso lauko slopimas, esant tik žemiesiems dažniams.

Grafikai rodo, kad esant žemiesiems dažniams, geriausias energijos slopimas yra impulso, kurio ilgis yra didžiausias. Tuo tarpu, kai salèje stovi tik kèdès, ilgiausias impulsas yra netinkamas skaičiavimams. Tai rodo, kad, nedaug pasiketus salès akustinèms savybèms. pasikeis ir optimalus impulso ilgis.

Lentelèje pateikiami maksimalūs energijos slopimai skirtingose salèse, kai skiriasi jų akustinès savybès ir yra skirtingi impulsų ilgiai.

\begin{tabular}{|c|c|c|c|c|c|c|c|c|c|c|c|}
\hline \multicolumn{12}{|c|}{ Dažniai. Hz } \\
\hline $\begin{array}{l}\text { Salè ir jos charakte- } \\
\text { ristika }\end{array}$ & $\begin{array}{l}\text { Impulsu } \\
\text { ilgiai, ms }\end{array}$ & 63 & 100 & 125 & 160 & 200 & 250 & 500 & 1000 & 2000 & 4000 \\
\hline \multirow{5}{*}{$\begin{array}{l}\text { Filharmonijos sale } \\
\text { su } 170 \text { kèdžių }\end{array}$} & 2500 & -29 & -35 & -40 & -41 & -45 & -50 & -60 & -60 & -60 & -55 \\
\hline & 3000 & -30 & -42 & -45 & -47 & -50 & -55 & -60 & -60 & -60 & -55 \\
\hline & 3500 & -30 & -43 & -45 & -50 & -52 & -55 & -60 & -60 & -60 & -55 \\
\hline & 4000 & -30 & -37 & -50 & -52 & -53 & -55 & -60 & -60 & -60 & -55 \\
\hline & 4500 & -33 & -42 & -50 & -52 & .53 & -55 & -60 & -60 & -60 & .55 \\
\hline \multirow{4}{*}{$\begin{array}{l}\text { Tokia pati salè. tik } \\
\text { joje yra } 60 \text { žiūrovy } \\
\text { ir kabo gobelenai }\end{array}$} & 1600 & -27 & -25 & -27 & -30 & -34 & -38 & -45 & -50 & -50 & -60 \\
\hline & 2000 & -30 & -37 & -33 & -35 & -43 & -50 & -55 & -65 & -60 & -60 \\
\hline & 2400 & -30 & -38 & -37 & -37 & -53 & -52 & -60 & -65 & -65 & -60 \\
\hline & 2800 & -35 & -37 & -43 & -43 & -53 & -58 & -60 & -65 & -65 & -57 \\
\hline \multirow{3}{*}{$\begin{array}{l}\text { "Viniaus" kino } \\
\text { teatras }\end{array}$} & 750 & -32 & -37 & -40 & -40 & -41 & .43 & -48 & -60 & -60 & -58 \\
\hline & 1000 & -30 & -35 & -40 & -40 & -42 & -43 & -50 & -58 & -58 & -58 \\
\hline & 1500 & -30 & -35 & -40 & -42 & -42 & -45 & .50 & -60 & -58 & -52 \\
\hline
\end{tabular}


$E, d B$

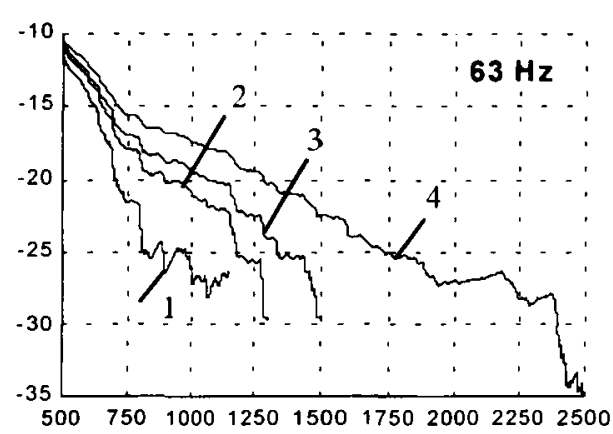

$E, d B$

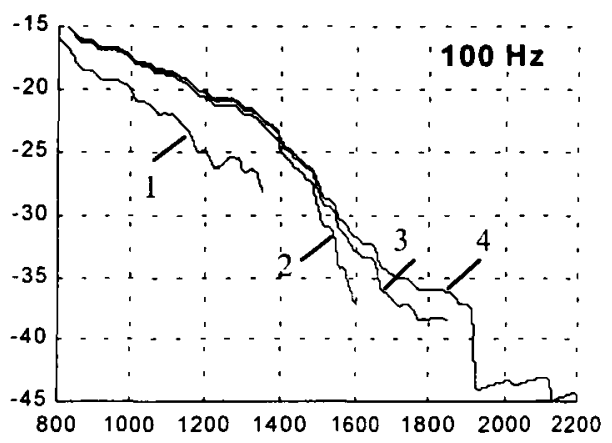

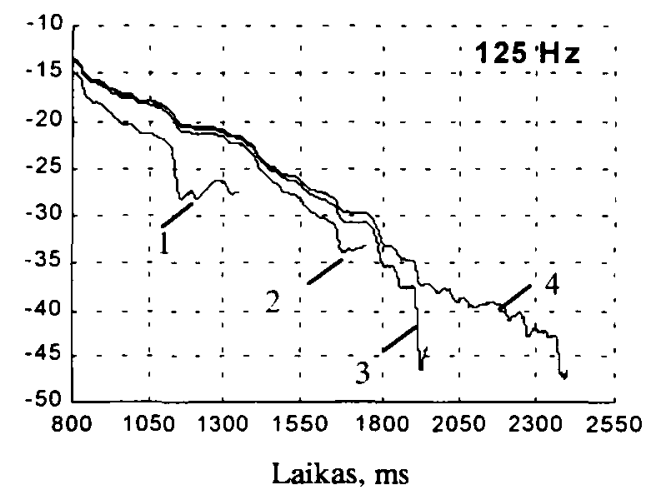

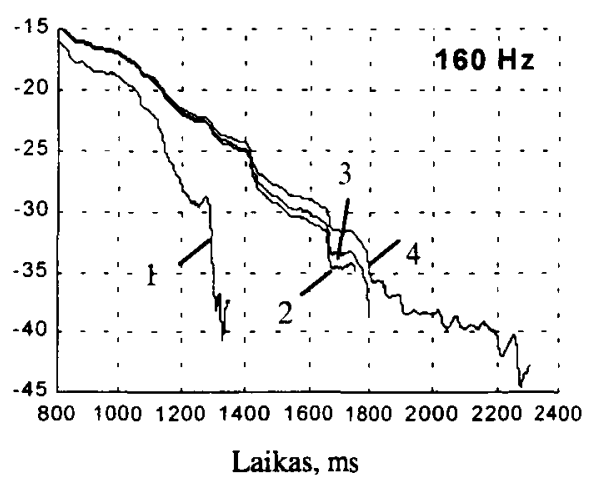

7 pav. Garso lauko energijos slopimas priklausomai nuo dažnio ir impulso ilgio. Salèje yra 170 kèdžių. 60 žiūrovų ir kabo gobelenai ant sienų. $1-1600,2-2000,3-2400,4-2800 \mathrm{~ms}$

Fig 7. The dependence of sound energy decrease on pulse length. Only 170 chairs in the hall, 60 listeners and tapestry on the walls. $1-1600,2-2000,3-2400,4-2800 \mathrm{~ms}$

\section{Išvados}

1. Impulsu ilgiai turi itakos maksimaliam garso lauko energijos slopimui.

2. Maksimaliai garso lauko energiją slopina didžiausio ilgio impulsas, tačiau tik esant žemiesiems dažniams.

3. Esant vidutiniams ir aukštiesiems dažniams pakankamas slopimas būna. kai impulsų ilgiai yra 3000$3500 \mathrm{~ms}$.

\section{Literatūra}

1. M. Vorlander, H. Bietz. Comparison of Methods for Meas uring Reverberation Time // Acustica, Vol 80, 1994, p. 205215

2 A. Lundeby, T. E. Vigran, H. Bietz, M. Vorlander. Uncertainties of Measurements in Room Acoustics // Acustica, Vol 81, 1995, p. 344-355.

3. Ning Xiang. Evaluation of reverberation times using a nonlinear regression approcch // J. Acoust. Soc. America, 98(4), October 1995, p. 2112-2121.

4. D. R. Morgan. A parametric error analysis of the backward integration method for reverberation time estimation // J. Acoust. Soc. America, 101 (5), Pt. 1, May 1997, p. 26862695.
5. M.R. Schroeder. New method of measuring reverberation time // J. Acoust. Soc. Amer. 1965, V. 37, No 3, p. 409412.

Iteikta 19991119

\section{PULSE LENGTH DEPENDENCE ON THE DECAY OF THE INTEGRATED PULSE ENERGY}

\section{J. Stauskis}

\section{Summary}

The paper deals with the influence of the pulse length on the decay of the sound field energy. Six pulse lengths -2000 , $2500,3000,3500,4000$ and $4500 \mathrm{~ms}$ - were selected for investigations.

Investigations show that a $2500 \mathrm{~ms}$ pulse is too short to correctly assess the background noise time interval. Such pulse length is not suitable for experiments. $3000 \mathrm{~ms}$ is the right length, while $3500 \mathrm{~ms}$ may be too long, resulting in errors of measurement results. When the pulse length increases to 4000 $\mathrm{ms}$, the decay starting from $2000 \mathrm{~ms}$ is different from the pulse length $2500 \mathrm{~ms}$ and $3000 \mathrm{~ms}$. Background noise starts from $2300 \mathrm{~ms}$ for these pulses, while for a $4000 \mathrm{~ms}$ pulse it starts from 3200 to $3300 \mathrm{~ms}$. The length of $4500 \mathrm{~ms}$ is completely not suitable for investigations because the background noise zone starts very early, ie at $1800 \mathrm{~ms}$, while for a shor $2500 \mathrm{~ms}$ pulse it starts much later, after $2300 \mathrm{~ms}$. 
While investigating energy decay, it is important to determine the maximum decay. At $63 \mathrm{~Hz}$ the sound field decay is almost uniform till $-18 \mathrm{~dB}$. Later the decay character is different. The decay of the longest $(4500 \mathrm{~ms})$ and the shortest $(2500 \mathrm{~ms})$ pulse after $-18 \mathrm{~dB}$ is very steep and reaches $-30 \mathrm{~dB}$. However, the decay is influenced by the background noise. Thus the shortest and the longest pulses are not suitable for the lowest frequencies. The greatest energy decay is characteristic of the $3000 \mathrm{~ms}$ pulse. After $1700 \mathrm{~ms}$ energy decreases $10-30$ $\mathrm{dB}$. Thus at this frequency one may measure the echoing time while approximating decay from 0 to $-20 \mathrm{~dB}$.

As the frequency increases, the results change. At $100 \mathrm{~Hz}$ the energy decays by $-35-37 \mathrm{~dB}$ at pulse lengths of $2500 \mathrm{~ms}$ and $4000 \mathrm{~ms}$. The greatest decay of $-42 \mathrm{~dB}$ is produced by the longest pulse $4500 \mathrm{~ms}$ though this arouses certain doubts. Then the echoing time may be measured from 0 to $-30 \mathrm{~dB}$.

At 125 octave frequency the smallest maximum decay of $-40 \mathrm{~dB}$ is observed with the shortest pulse $(2500 \mathrm{~ms})$, while the largest one $-50 \mathrm{~dB}$ is produced by the longest pulse $(4500 \mathrm{~ms})$. Thus standard echoing time may be measured for this frequency.

In the frequency range of $250-2000 \mathrm{~Hz}$, the maximum energy decay is sufficient and amounts to $-50-60 \mathrm{~dB}$. At 4000 $\mathrm{Hz}$ the final part of decay is strongly dependent on the pulse length although, as the decay is about $-55 \mathrm{~dB}$ in all cases, the standard echoing time may be measured correctly.
Pulse length is important only for the calculation of the low-frequency echoing time. At $63-100 \mathrm{~Hz}$ the best maximum decay is seen with the pulse $3000 \mathrm{~ms}$ long, while at $125 \mathrm{~Hz}$ and over the best pulse lengths are from 3000 to $4000 \mathrm{~ms}$. When the hall contains audience and tapestries are on the walls, the energy decay is almost uniform at the pulse lengths of 2000 to $2800 \mathrm{~ms}$. In this case a better decay is obrained with the longest pulse of $2800 \mathrm{~ms}$.

Vytautas STAUSKIS. Doctor Habil. Professor. Dept of Building Structures. Vilnius Gediminas Technical University (VGTU). Sauletekio al. 11. LT-2040 Vilnius, Lithuania.

E-mail: Stat@ar.vtu.lt

Doctor (1974), Doctor Habil (1977). From 1974 at VGTU

Dept of Building Structures. Research visits: Moscow Civil Engineering Institute, Sanki-Petersburg Politechnic Institute. Research interests: experimental testing of halls by primary hall models and on site, computer simulation of theoretic tasks, wave diffraction and reflections, direct sound and subjective acoustic indicators, large-scale resonance structures, early attenuation of acoustic field and its relation to hall acoustics. 